\title{
Regional financial performance and human development index: Study in Central Java and South Kalimantan provinces
}

\author{
Sri Suranta \\ Sebelas Maret University, Surakarta, Indonesia \\ srisuranta@yahoo.com \\ Bandi Bandi \\ Sebelas Maret University, Surakarta, Indonesia \\ Halim Dedy Perdana \\ Sebelas Maret University, Surakarta, Indonesia \\ Muhammad Syafiqurrahman \\ Sebelas Maret University, Surakarta, Indonesia
}

Follow this and additional works at: https://journal.uii.ac.id/jca

Copyright (C2019 Journal of Contemporary Accounting and Authors.

To cite this article: Sri Suranta, Bandi Bandi, Halim Dedy Perdana, Muhammad Syafiqurrahman. (2019). Regional financial performance and human development index: Study in Central Java and South Kalimantan provinces. Journal of Contemporary Accounting, 1(2), 85-94. doi:10.20885/jca.vol1.iss2.art2 


\title{
Regional financial performance and human development index: Study in Central Java and South Kalimantan provinces
}

\author{
Sri Suranta, Bandi Bandi, Halim Dedy Perdana, Muhammad Syafiqurrahman
}

Sebelas Maret University, Surakarta, Indonesia

\section{JEL Classification: \\ R5 1,015}

\section{Keywords:}

regional government financial performance, human development index, people's prosperity.

\section{Corresponding Author:} srisuranta@yahoo.com

DOI:

10.20885/jca.vol 1.iss2.art2

Copyright (C) 2019

This is an open access under CC-BY-SA license

\begin{abstract}
The purpose of this study is to find out: (1) the difference Human Development Index (HDI) between Central Java Province and South Kalimantan Province, and (2) the effect of the financial performance of the Regional Government on HDI. The samples of this study were the city and regency in the Provinces of Central Java and South Kalimantan. This study found that there were differences in the level of people's prosperity as reflected by HDI between Central Java and South Kalimantan. Other finding showed that the financial performance of the Regional Government affected the level of people's prosperity as measured by HDI.
\end{abstract}

\section{Introduction}

With regional autonomy, Regional Governments are mandated to carry out several tasks. One of the main tasks of the Regional Government listed in the Law of Regional Government Number 32 of 2004 is to carry out the broadest autonomy, except those belonging to central governmental affairs, with the aim to improve people's welfare, public services, and regional competitiveness. Human development which is reflected in the Human Development Index (HDI) is highly dependent on the commitment of the government in providing supporting facilities. One of the most important elements in the government administration and regional development is regional finances managements which meet the development aspirations and the demands of the people. In the context of realizing regions with high human quality, regional governments use the Regional Budget to finance developments in these sectors. Local governments must work hard to reduce the poverty rate. The low capacity and capability of regional finances management often bring a negative effect, namely the low-quality service for the people and not being able to improve HDI. Government performance which is often used as a reference in viewing the level of public welfare is the financial performance. There are many measuring instruments to assess the government financial performance, including the analysis of financial ratios to the Regional Budget of Revenue and Expenditure (Harliyani \& Haryadi, 2016).

Previous studies have proven the influence of local government financial performance on HDI. Indramawan (2018)examined the performance of Local Governments and HDI in the provinces of West Papua and Papua. The result showed that the Fiscal Decentralization Ratio had a positive impact on HDI in both provinces. Meanwhile, The Regional Government's 
Financial Dependency Ratio, as well as the Capital Expenditure Ratio had a negative impact on HDI in both provinces. Ananda (2017) found that the Fiscal Decentralization Degree Ratio, the Regional Financial Independence Ratio and the Regional Original Revenue Effectiveness Ratio had a significant effect on HDI. On the other hand, the Regional Financial Efficiency Ratio, and Capital Expenditure Allocation did not affect the HDI. Harliyani and Haryadi (2016) stated that the ratio of the degree of fiscal decentralization and the expenditure balance directly affected HDI, while the three variables namely the regional financial dependency ratio, the effectiveness of regional original revenue and the efficiency of regional original revenue did not affect on HDI.

Based on the description above, the problems of this study are: 1) Is there any difference in the level of people's welfare as measured by the Human Development Index (HDI) between Central Java and South Kalimantan? 2) Does the Regional Government Financial Performance affect HDI in Central Java and South Kalimantan? This research was conducted to find out differences in the Human Development Index between Central Java and South Kalimantan. Besides, it also aimed to find out whether the Regional Government's financial performance affects the HDI in both provinces. The results of this study are expected to contribute to the Government as a consideration for making policies related to equitable development. In addition, the government must pay attention to the importance of the financial performance of local governments to improve the prosperity of the people.

\section{Literature Review}

\section{Agency Theory in Government}

From the perspective of agency theory, the relationship between society and government is like the relationship between principals and agents. The community is the principal and the government is the agent. Principals give authority to regulate agents, and authorize resource management to agents (in the form of taxes and others) (Prasetyaningsih, 2014). Since the implementation of the regional autonomy system, each region has been given authority by the central government to take care of its own household affairs based on the initiatives and aspirations of its people within the framework of the unitary state of the Republic of Indonesia. Based on Law number 23 of 2014 in lieu of Law Number 32 of 2004 and the previous law on Regional Government, there is a strict separation between the function of the regional government (executive) and the function of the people's representatives (legislative). Based on the differentiation of these functions, the executive carries out the planning, implementation and reporting of the regional budget which is a manifestation of service to the public. Whereas the legislative who is a community representative plays an active role in implementing legislation, budgeting, and supervision (Halim \& Abdullah, 2006).

\section{Regional Government Financial Performance}

Financial performance is a performance measurement that uses financial indicators. According to Munir et al. (2004), some ratios that can be developed based on financial data sourced from the Regional Budget are as follows: (1) Regional Financial Independence Ratio. Regional financial independence (fiscal autonomy) shows the ability of regional governments to fund their activities, development, and services to the people who have paid taxes and retributions as sources of revenue needed by the region. The independence of regional finances is shown by the size of the regional original revenue compared to regional revenue that comes from other sources, for example, central government grants or from loans. The independence ratio illustrates the region's dependence on external funding sources. The higher the ratio of independence means that the level of regional dependence on external parties (especially the central and provincial governments) is lower, and vice versa. The ratio of independence also illustrates the high level of people participation in paying taxes and retributions which are the main components of regional 
original revenues. The higher the people pay taxes and regional retributions, the higher the level of people's welfare will be, (2) Fiscal Decentralization Degree Ratio. This measure shows the authority and responsibility given by the central government to regional governments to explore and manage revenue. This ratio is intended to measure the level of contribution of Regional original Revenue as a source of self-managed revenue to the total regional revenue. Regional original revenue is the revenue derived from the results of regional taxes, regional retribution, regional owned companies and the management of regional property and other legitimate revenues. Total Regional Revenue is the sum of all revenues in one fiscal year, and (3) Regional Original Revenue Effectiveness Ratio. The effectiveness ratio illustrates the ability of local governments in realizing planned Regional Original Revenue compared to targets set based on the real potential of the region. The ability of the regions to carry out their tasks is categorized as effective if it reaches a minimum of 1 (one) or 100 percent. The higher the ratio of effectiveness, the better the ability of the region.

\section{Human Development Index (HDI)}

HDI explains how people can access the results of development in obtaining income, health, education, and so on. HDI was firstly introduced by the United Nations Development Program (UNDP) in 1990 and it is published regularly in the annual Human Development Report (HDR) report. HDI is formed by 3 (three) basic dimensions: (1) long life and healthy living, (2) knowledge, and (3) decent standard of living. Benefits of HDI are: (1) HDI is an important indicator to measure success in the efforts of building human life quality (community/people). (2) HDI can determine the ranking or level of development of a region/country, and (3) For Indonesia, HDI is strategic data, because it is not only being a measure of Government performance but also used as one of the aspects in determining the General Allocation Fund (DAU) (BPS, 2014).

\section{Previous Researches and Hypothesis Development}

Indramawan (2018) examined the impact of regional government financial performance on the Human Development Index (HDI) on regencies and cities in the provinces of West Papua and Papua. Both provinces were taken because they have the lowest HDI levels in Indonesia. To measure the financial performance of the regional governments, this study used several ratios, namely Fiscal Decentralization Ratio, Regional Government Financial Dependency Ratio, Regional original Revenue Effectiveness Ratio, and Capital Expenditure Ratio. The data in this study were panel data that were a combination of cross-section and time series. The regression model used was the Fixed Effect Model (FEM). The results of the study were the Fiscal Decentralization Ratio had a significant positive impact on HDI in West Papua and Papua. Regional Government Financial Dependency Ratio and Capital Expenditure Ratio had a significant negative impact on HDI in both provinces. Variable of Effectiveness Ratio of Regional Original Revenue had a negative effect on HDI, but not significant.

Ananda (2017) conducted a study to find out the influence the Regional Government Financial Performance, namely in the form of Fiscal Decentralization Degree Ratio, Regional Financial Independence Ratio, Regional Original Revenue Effectiveness Ratio (PAD), Regional Financial Efficiency Ratio, and Capital Expenditure Allocation Ratio to Human Development Index (HDI) in 38 regencies/cities in East Java Province in 2011-2015. The data analysis tool was panel data analysis. The data of this research were secondary data. Based on the results of tests, it showed that: (1) Ratio of Fiscal Decentralization Degree had a significant effect on HDI, (2) Ratio of Regional Financial Independence and Regional Original Revenue Effectiveness affect the HDI, (3) Ratio of Regional Financial Efficiency had no effect on HDI, and (4) Ratio of capital expenditure allocation had no effect on HDI. From these results, the Government of 
East Java Province was considered to be able to provide an optimal portion of the sectors that support the improvement of people's welfare, namely by optimizing its expenditure on capital expenditure for public services compared to operational expenditure and employee expenditure.

Harliyani and Haryadi (2016) conducted a study to analyze the development of regional revenue and expenditure in Jambi Province. It was aimed to analyze the financial performance seen from the ratio of fiscal decentralization degree, regional financial dependency, regional independence, effectiveness of regional original revenue, efficiency of regional original revenue and the balance of direct expenditure, as well as to analyze the effect of financial performance on the Human Development Index (HDI). The method of analysis used descriptive statistical method by describing and explaining data that had been collected descriptively, namely the status/level of the observed variables in the form of ratios/percentages, graphical tables or diagrams, and by using several classic assumption test analysis tools, multiple linear regression and hypothesis testing. The results showed that: among the research variables, only 2 (two) variables significantly influenced the HDI, namely the ratio of fiscal decentralization degree and the balance of direct expenditure. Meanwhile, the other three variables namely the ratio of regional financial dependence, the effectiveness of regional original revenue and the efficiency of regional original revenue did not significantly affect the HDI. Based on the research findings, it was concluded that the HDI in Jambi Province in the period of 2001-2014 was influenced by the ratio of the fiscal decentralization degree and the balance of direct expenditure.

Agency problems that occur between the government and the community can be minimized by achieving good performance by the government. The community as a principal can see and measure how the results of local government performance. The government must be able to manage and measure its performance by using a correct performance measurement system in order to provide better services to the community and get community support (Nurdin et al., 2014).

Based on the description and previous studies, the hypothesis proposed are as follows.

H1: There are differences in the Human Development Index between the Provinces of Central Java and South Kalimantan.

H2: Regional Government Financial Independence influences the Human Development Index (HDI).

H3: Regional Government Fiscal Decentralization influences the Human Development Index (HDI).

H4: Effectiveness of Regional Original Revenue influences the Human Development Index (HDI).

\section{Research Framework}

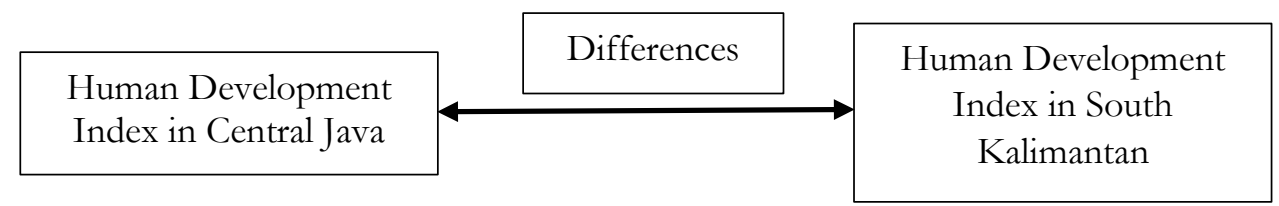

Figure 1. Model 1 Differences in Human Development Index

Financial performances of regional government:

1. Financial independence

2. Fiscal decentralization

3. Regional original revenue effectiveness

Figure 2. Model 2 Financial performances of regional government and HDI 


\section{Research Methodology}

\section{Research Population and Samples}

The population of this research were the regency/city governments in the provinces of Central Java and South Kalimantan using a purposive sampling data collection method to obtain samples that meet the criteria. The samples of this study were selected based on the following criteria: (1) District and City Government Financial Statements in Central Java and South Kalimantan from 2014 to 2017, and (2) Receiving Unqualified opinion and Qualified opinion from Supreme Audit Board of the Republic of Indonesia which contains reliable information.

\section{Research Variables}

The variables used in this study were independent variables, namely the financial performance of the Regional Government which included several parameters in the form of ratios according to Munir et al. (2004) consisting of: (1) Independence Ratio (IR), this variable is calculated by Total regional original revenue divided by Grants from central government and loan, (2) Fiscal Decentralization Ratio (FDR), this variable is calculated by Total regional original revenue divided by Total regional revenue, and (3) Regional Original Revenue Effectiveness Ratio (RORER), this variable is calculated by Total Regional Original Revenue realization revenue divided by Total regional revenue.

The dependent variable in this study was the Human Development Index (HDI). It was calculated as a geometric average of the health, education, and expenditure indices. This variable is calculated by the following formula.

$$
H D I=\sqrt[2]{I_{\text {health }} x I_{\text {education }} x I_{\text {exp enditure }}} x 100
$$

\section{Data Types and Sources}

This research used secondary data. The data in this study were in the form of Regional Government Financial Statements that have been audited by the Indonesian Supreme Audit Board. This research traced several documents in the form of annual financial statements of the regional government that had been audited by the Indonesian Supreme Audit Board in the period of 2014 to 2017. In addition, the study used Human Development Index (HDI) data. This data was obtained from the Central Statistics Agency (BPS).

\section{Data Analysis and Hypothesis Testing}

Before the hypothesis test was performed, an analysis of the data normality was done to determine the method to test the results of the research. This analysis was needed to determine whether the research data had a normal distribution or not. This normality analysis was a requirement of the different tests for two independent samples (model 1) and multiple regression tests (model 2). To detect the data normality in this study, a non-parametric test, KolmogrovSmirnov test, was used. There were some possible choices of statistical test tools on the results of the study after the normality test. For Model 1, if the results of the normality test resulted in a normal distribution of financial ratios, then the independent sample t-test was performed, but if the normality test results in an abnormal distribution of financial ratios, so the Mann-Whitney Utest was used for different ratios.

For Model 2 test, there were several possible choices of statistical test tools on the results of the study after the normality test. If the results of the normality test results in a normal distribution, then the ratios were tested using multiple regression test, but if the data normality test results in an abnormal distribution, then the run test was performed to that ratios. 


\section{Results and Discussion}

\section{Population and Sample}

The population of this research were all regency and city in Central Java and South Kalimantan. The total population of the two provinces were 36 regency and city in Central Java and 14 regency and city in South Kalimantan. The research sample can be seen in the following table.

Table 1. Research Sample

\begin{tabular}{lr}
\hline \multicolumn{1}{c}{ Items } & Total \\
\hline Regency and city population in 2014-2017 & 200 \\
Provincial data & $(8)$ \\
Incomplete data & $(30)$ \\
Research samples & 162 \\
\hline
\end{tabular}

\section{Descriptive Statistic}

Table 2. Descriptive statistic

\begin{tabular}{lcrrrr}
\hline \multicolumn{1}{c}{ Items } & N & Minimum & Maximum & \multicolumn{1}{c}{ Mean } & Std. Deviation \\
\hline HDI & 162 & 61,32 & 81,68 & 69,5380 & 4,51051 \\
IR & 162 & 6,00 & 81572,00 & 753,6296 & 6564,24227 \\
FDR & 162 & 5,00 & 53,00 & 14,9074 & 6,37425 \\
RORER & 162 & 2,00 & 53,00 & 8,8827 & 5,49125 \\
\hline Source: & & & & &
\end{tabular}

Based on table 2, the lowest HDI during 4 years (2014 to 2017) for Central Java Province is 61.32, namely Pemalang Regency in 2014 and the highest is 81.68, namely Semarang City in 2017.

\section{Normality Test}

Table 3. Results of normality test

\begin{tabular}{lrr}
\hline \multicolumn{2}{c}{ One-Sample Kolmogorov-Smirnov Test } \\
\hline N & Unstandardized Residual \\
Normal Parameters,b & 162 \\
& Std. Deviation &, 0000000 \\
Most Extreme & Absolute & 3,97394768 \\
Differences & Positive &, 102 \\
& Negative &, 102 \\
Kolmogorov-Smirnov Z & &,- 046 \\
Asymp. Sig. (2-tailed) & & 1,297 \\
\hline a. Test distribution is Normal. &, 069 \\
b. Calculated from data. &
\end{tabular}

By using the Kolmogorov-Smirnov Test, the data of this study are normal because the significance value of the Kolmogorov-Smirnov test is 0.069 greater than 0.05. Based on these results, the hypothesis test in this study used the Multiple Regression Test. 


\section{Hypotheses Testing}

\section{Results of Hypothesis 1 Test}

Table 4. Group statistic of hypothesis

\begin{tabular}{llrrrr}
\hline & Provinces & N & \multicolumn{1}{c}{ Mean } & Std. Deviation & \multicolumn{1}{c}{ Std. Error Mean } \\
\hline \multirow{2}{*}{ HDI } & Central Java & 123 & 70,0948 & 4,47566 &, 40356 \\
& South Kalimantan & 39 & 67,7818 & 4,20912 &, 67400 \\
\hline
\end{tabular}

Source: analyzed data

Table 5. Results of hypothesis 1 testing

\begin{tabular}{|c|c|c|c|c|c|c|c|c|c|}
\hline \multicolumn{10}{|c|}{ Independent Samples Test } \\
\hline \multirow[t]{2}{*}{ HDI } & \multirow[t]{2}{*}{$\mathrm{F}$} & \multirow[t]{2}{*}{ Sig. } & & \multirow{2}{*}{$\begin{array}{l}\text { Levene's } \\
\text { Test for } \\
\text { Equality of } \\
\text { Variances }\end{array}$} & \multirow[t]{2}{*}{$\begin{array}{l}\text { t-test for } \\
\text { Equality of } \\
\text { Means }\end{array}$} & \multirow[t]{2}{*}{$\begin{array}{c}\text { Mean } \\
\text { Diff. }\end{array}$} & \multirow[t]{2}{*}{$\begin{array}{l}\text { Std. } \\
\text { Error } \\
\text { Diff. }\end{array}$} & \multicolumn{2}{|c|}{$\begin{array}{l}95 \% \text { Confidence } \\
\text { Interval of the } \\
\text { Difference }\end{array}$} \\
\hline & & & & & & & & Lower & Upper \\
\hline Equal variances assumed & 1,205 & 274 & 2,852 & 160 & ,005 & 2,31300 & ,81112 &, 71111 & 3,91489 \\
\hline Equal variances not assumed & & & 2,944 & 67,431 & ,004 & 2,31300 & ,78558 & ,74517 & 3,88084 \\
\hline
\end{tabular}

Source: analyzed data

Based on tables 4 and 5 , the significance value of the t-test is 0.004 . This value is smaller than the alpha significance value which is set 0.05 . This means that hypothesis 1 is accepted. There are differences in HDI between the Provinces of Central Java and South Kalimantan. On average, the HDI of Central Java Province is 70.09 higher than the HDI of South Kalimantan Province which is only 67.78 .

\section{Results of Hypotheses 2, 3, and 4 Tests}

Table 6. Model test results

\begin{tabular}{|c|c|c|c|c|c|c|}
\hline \multicolumn{7}{|c|}{ ANOVA $^{a}$} \\
\hline Model & & Sum of Squares & df & Mean Square & $\mathrm{F}$ & Sig. \\
\hline \multirow{3}{*}{1} & Regression & 732,949 & 3 & 244,316 & 15,182 &, $000^{\mathrm{b}}$ \\
\hline & Residual & 2542,554 & 158 & 16,092 & & \\
\hline & Total & 3275,503 & 161 & & & \\
\hline \multicolumn{7}{|c|}{ a. Dependent Variable: IPM } \\
\hline \multicolumn{7}{|c|}{ b. Predictors: (Constant), Efektif, RKem, Rdes } \\
\hline
\end{tabular}

Based on table 6, the model tested in this study is fit capital. It is proven by the significance value of $\mathrm{F}$ which is less than the determined value of 0.05 .

Based on table 7 , the results of this study indicate that the variability of independent variables in influencing the dependent variable is $20.9 \%$. Meanwhile, $79.1 \%$ of the dependent variable in this study was influenced by other variables.

Based on table 8, the Regional Government Financial Performance as measured by the Regional Financial Independence Ratio, Fiscal Decentralization Ratio, and Regional original revenue Effectiveness Ratio affect the level of people's welfare as measured by the Human Development Index (HDI). This is indicated by the significance value of $t$ of all independent variables which are smaller than the alpha value specified, which is 0.05 , which means hypotheses 2,3 , and 4 are accepted. 
Table 7. Determination Coefficient Value

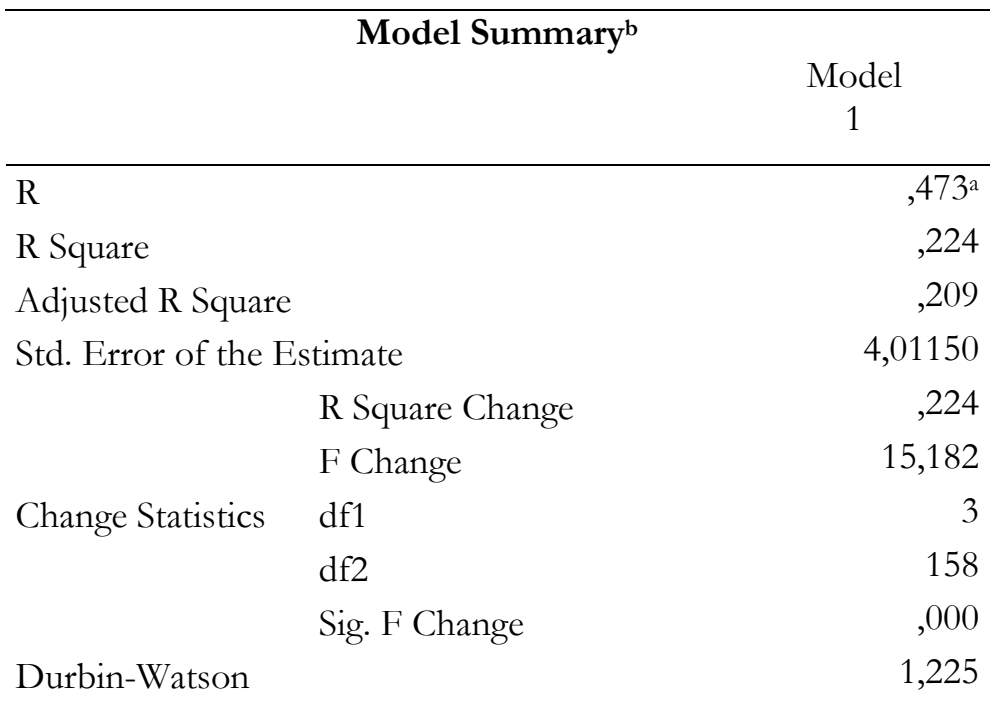

a. Predictors: (Constant), IR, FDR, RORER

b. Dependent Variable: HDI

Table 8. Results of Hypotheses 2, 3, dan 4 Tests

\begin{tabular}{llrrrr}
\hline & & \multicolumn{4}{c}{ Model 1} \\
& & (Constant) & \multicolumn{1}{c}{ IR } & FDR & RORER \\
\hline \multirow{2}{*}{ Unstandardized Coefficients } & B & 64,302 &, 000 &, 570 &,- 380 \\
Standardized Coefficients & Std. Error &, 919 &, 000 &, 134 &, 161 \\
$\mathrm{t}$ & Beta & &, 201 &, 806 &,- 462 \\
Sig. & & 69,932 & 2,597 & 4,268 & $-2,359$ \\
95.0\% Confidence Interval for & Lower Bound &, 000 &, 010 &, 000 &, 020 \\
B & Upper Bound & 62,486 &, 000 &, 307 &,- 698 \\
& Zero-order & &, 000 &, 834 &,- 062 \\
Correlations & Partial & &, 220 &, 424 &, 350 \\
& Part & &, 182 &, 322 &,- 184 \\
Collinearity Statistics & Tolerance & &, 824 &, 138 &,- 165 \\
& VIF & & 1,214 & 7,262 & 7,817 \\
\hline
\end{tabular}

a. Dependent Variable: HDI

Based on the results of data analysis and hypothesis testing, the findings of this study show that there are differences in the level of welfare as measured by the Human Development Index (HDI) between Central Java and South Kalimantan. In addition, the average HDI of Central Java is higher than the HDI of South Kalimantan. This study supports Hill's research that eastern Indonesia is still lagging behind the western region because eastern Indonesia has always been poorer. Eastern Indonesia is still underdeveloped. Although lagging behind other provinces, eastern Indonesia is also advanced in terms of growth. There is not too much difference between western Indonesia and eastern Indonesia. Because eastern Indonesia was poorer in the past, the 
growth rate was not as high as the western regions, so the gap was getting bigger and bigger (Antaranews.com, 2007).

Other finding shows that Regional Government Financial Performance as measured by the Regional Financial Independence Ratio, Fiscal Decentralization Ratio, and Effectiveness of Regional Original Revenue affect the level of welfare as measured by HDI. The results of this study support research conducted by Harliyani and Haryadi (2016), and Ananda (2017). The results support agency theory, the community is the principal give authority to regulate government (agents), and authorize resource management to agents (in the form of taxes and others) in order to increase community (principal) welfare. The results of this study have contributions to the Government as a consideration for making policies related to equitable development. In addition, the government must pay attention to the importance of the financial performance of local governments to improve the prosperity of the people.

\section{Conclusion}

The conclusions of this study are: (1) there is a difference in the level of prosperity between the province of Central Java which is in the Western Indonesia Region and the Province of South Kalimantan which is the Eastern Indonesia Region, and (2) the Financial Performance of the Regional Government as measured by the independence ratio, the fiscal decentralization ratio, and the effectiveness of Regional Original Revenue affect the HDI.

This study has the following limitations. The variability of the independent variable is only $20.9 \%$, which means $79.1 \%$ is influenced by other variables, so it is recommended for future research to include other independent variables in the model, such as the General Allocation Fund, Special Allocation Fund, and Capital Expenditures. The sample of this study only took 1 province of Western Indonesia, namely Central Java and 1 province of Eastern Indonesia, namely South Kalimantan. Future research should take samples from more than 1 provinces in both the West and East Indonesia to get more representative results.

\section{References}

Ananda, E. A. V. (2017). Analisis Pengarub Kinerja Kenangan Pemerintah Daerah Terhadap Indeks Pembangunan Manusia pada 38 Kabupaten/Kota di Provinsi Jawa Timur Tabun 2011-2015. Universitas Sebelas Maret.

Antaranews.com. (2007, May 23). Pertumbuhan di Indonesia Barat dan Indonesia Timur Merata, Kata Ekonom ANU. Antara.

BPS. (2014). Indekes Pembangunan Manusia 2014. Badan Pusat Statistik.

Halim, A., \& Abdullah, S. (2006). Hubungan dan masalah keagenan di pemerintah daerah: Sebuah peluang penelitian anggaran dan akuntansi. Jurnal Akuntansi Pemerintahan, 2(1), 5356.

Harliyani, E. M., \& Haryadi, H. (2016). Pengaruh kinerja keuangan pemerintah daerah terhadap indeks pembangunan manusia di provinsi Jambi. Jurnal Perspektif Pembiayaan Dan Pembangunan Daerah, 3(3), 129-140.

Indramawan, D. (2018). The impacts of financial performance of local governments on human development index in Papua. Simposium Nasional Kenangan Negara, 1248-1272.

Munir, D., Djuanda, H. A., \& Tangkilisan, H. N. S. (2004). Kebijakan Dan Manajemen Kenangan Daerah. Yayasan Pembaruan Administrasi Publik Indonesia.

Nurdin, N., Stockdale, R., \& Scheepers, H. (2014). Coordination and cooperation in e- 
Regional financial performance and human development index: ...

government: An Indonesian local e-government case. The Electronic Journal of Information Systems in Developing Countries, 61(1), 1-21.

Prasetyaningsih, E. (2014). Pengaruh Karakteristik Kenangan Daerah dan Temuan Audit Terhadap Kinerja Pemerintah pada Pemerintah Daerah se-Indonesia. Universitas Sebelas Maret. 